(C) 2018 International Journal of Nursing and Midwifery Science(IJNMS)

This is an Open Access article distributed under the terms of the Creative CommonsAttribution 4.0 International License which permits unrestricted noncommercial use, distribution, and reproduction in any medium, provided the original work is properly cited.

\title{
Improving Nursing Student Learning Achievements in Islamic Religion Subject Using Cooperative Methods Team Assisted Individually (Tai) Model at School of Health Bina Sehat PPNI Mojokerto
}

\author{
ARIF EFENDI ${ }^{1}$, ASEF WILDAN MUNFADLILA ${ }^{2}$, MOH. ZAINUDIN ${ }^{3}$ \\ Bina Sehat PPNI health science institute Mojokerto regency East Java Indonesia \\ Email correspondent: arifendi2018@gmail.com, acheif90@gmail.com, z.udin71@yahoo.co.id,
}

\section{ABSTRACT}

Islamic Education is an effort in the form of guidance and care for students so that after completing their education they can understand and practice the teachings of Islam and make it a way of life. The real purpose of this study is to find out the effect of using cooperative methods Assisted Individually Team (TAI) towards improving the learning achievement of Islamic religious studies for undergraduate students in Nursing School of health Bina Sehat PPNI Mojokerto. To realize this goal, more in-depth research is needed, namely by using quantitative methods with the type of quasi-experiment with the form of one group pre-test and post-test design. The population of the study was the 2nd-semester students of class 1E 2017-2018 academic year at S1 Nursing School of health Bina Sehat PPNI Mojokerto. Sampling technique used class $1 \mathrm{E}$ purposive sampling technique for the second semester with 43 students. The results of the t-test were found to be $0,00<\mathrm{p}$ value means that Ho was rejected and $\mathrm{Hi}$ was accepted, meaning that there was a significant influence on the use of cooperative methods assited individualy team type on learning achievement in Islamic religious courses.

\section{Keywords}

Nursing

Students,

Islamic

Education,

Learning

Outcomes,

Team

Assisted

Individuals 


\section{INTRODUCTION}

Along with the progress of the flow of information, transformation, science, and technology, competitiveness in all areas of life is very tight especially to get jobs. Therefore superior, reliable and quality human resources are needed, and one of the government's efforts to overcome the above problems is by improving the quality of education.

As stated in the education curriculum law Law No. 12 of 2012 (Finkelstein 1951)concerning Higher Education: "Implementation of Higher Education education and every compulsory study program are presented and developed through curriculum as an instrument and document so that the education process can run well, controlled, organized and focused so that it can deliver special academic qualifications and abilities and skills" . and Law No. 20 of 2003 concerning the National Education System states: "Efforts for students to develop their potential to have religious, spiritual strength, intelligence, superior personality, noble morality, and special abilities needed by society, religion, religion, and nation are through the education system"(Duflo 2001) ".

Education is an activity that involves every individual, individual, family and all levels of society. Every individual from the mother's mother to the end of her life needs education, whether it's an education for themselves, children, (family) or the community. Even in the GBHN (MPR decree No. IV / MPR / 1978), with regard to Education it was stated that, "Education is a shared responsibility between family, society, and government because education takes a lifetime and is carried out within the scope of the household, school, and society"(Development and Bank 2015).
One effort that can be made to achieve this goal is the availability of adequate teaching materials. In the learning process in the classroom, teaching materials become one of the supporting components to achieve learning goals. "Teaching materials themselves have the understanding of all forms of material (both information, tools, and texts) which are arranged systematically, which displays a complete figure of competencies that will be mastered by students and used in the learning process with the aim of planning and reviewing the application of learning, modules, handouts, worksheets, models, audio, etc. (Pashler et al. 2009)

Cooperative learning or what is often referred to as group learning has a variety of types, but what you want to apply in this study is the type of Team Assisted Individually (TAI) that can be used to increase the effectiveness of learning in the Islamic religion. The Team Assisted Individually (TAI) learning model is a learning model that forms heterogeneous small groups with different ways of thinking to help each other students who need help (Johnson, Johnson, and Stanne 2000). This learning model was developed by Slavin for several reasons, among others. First, this model combines cooperative excellence and individual teaching programs. Second, this model puts pressure on the social effects of cooperative learning. Third, TAI is structured to solve problems in teaching programs, for example regarding individual student learning difficulties (Wenger 1999). Theories developed by Slavin are by those developed by (Wati, Utomo, and Redjeki 2014) that student achievement is better using methods cooperative TAI rather than traditional learning. 


\section{METHOD}

In this research. The research method used is the Pre method Experimental Design (Latuconsina 2018). This research was conducted in one class, namely class $1 \mathrm{E}$ Semester 2, 2017-2018 Academic Year in S1 Nursing School of Health Bina Sehat PPNI Mojokerto using the Team Assisted Individually (TAI) method.

in various ways, Of course, a study requires an appropriate method for the sake of achievement of the objectives of the study. The technique used in this study is a Pre Experimental Design research method with One research design Group Pre-test - Posttest. Because researchers want to get better results by comparing. (Sugiono 2016)Revealed that this design uses a pretest and post-test, before obtaining a better assessment, the researcher conducts a pretest first, and the post-test is done after getting the material in the hope that there is a comparison between before the material is given and after the given element in the implementation of this study using a control class very difficult. Then only one level is used, namely the experimental class (Semester 1E Semester 2 2017-2018 Academic Year at S1 Nursing School of Health Bina Sehat PPNI Mojokerto).

The design used is One Group Pre-test Post-test that is design the observations were made twice namely before the experiment and after the experiment. Observations made before the experiment are called pre-test, and observation after the experiment is called post-test. The chart can be described as follows:

\begin{tabular}{|l|c|c|c|}
\hline Kelompok & Pre-test & Perlakuan & Post-test \\
\hline Eksperimen & $\mathrm{T}_{1}$ & $\mathrm{X}$ & $\mathrm{T}_{2}$ \\
\hline
\end{tabular}

Note:

$\mathrm{Ti}=\{$ pre-test $)$

$\mathrm{T} 2=($ post-test $)$

$\mathrm{X}=$ Team Assisted Individually(TAI)

The research variables consisted of 2, namely independent variables. While the variables due to are also called dependent variables, the two research variables are the variables used in this study. The independent variable is Team Assisted Individually, while the dependent variable signifies student learning outcomes in the Islamic Religion course. Based on the type, the data in this study are quantitative data in the form of student learning outcomes taken from the results of the test, both pre-test and post-test for learning achievement Islamic Studies at School of Health Bina Sehat PPNI Mojokerto. Second semester who attended lectures on Islamic Religion at School of Health Bina Sehat PPNI Mojokerto 20172018 school year as many as 200 students. The sample in this study was taken one class with the sampling technique using purposive sampling technique, namely the technique of determining the sample based on the consideration of the researcher. The sample in this study was as many as 43 people namely the experimental class. The class designated as the experimental class is class 1-E. A research instrument is a tool or facility used by researchers in collecting data so that their work is easier and the results are better. The instrument used in this study was a written test of 20 items. The question is used in the pre-test and post-test. The purpose of using the same questions in the pre-test and post-test is to find out the improvement in the learning achievement of Islamic subjects after getting treatment. It is more careful, complete, and systematic so that it is easier to process (Cohen, Manion, and Morrison 2011). 
RESULT

\section{GENERAL DATA}

Table 1 Results of pre-test post-test for $1 \mathrm{E}$ grade students of 2 Stikes Bina Sehat PPNI Mojokerto 2017-2018 school year.

\begin{tabular}{lccc}
\hline & N & MINIMUM & MAXIMUM \\
\hline $\begin{array}{l}\text { Pre- } \\
\text { test }\end{array}$ & 43 & 65 & 80 \\
\hline $\begin{array}{l}\text { Post- } \\
\text { test }\end{array}$ & 43 & 75 & 100 \\
\hline
\end{tabular}

\section{SPECIFIC DATA}

Table 3 Descriptive statistical analysis of $1 \mathrm{E}$ grade students 2 Stikes Bina Sehat PPNI Mojokerto 2017-2018 school year

\begin{tabular}{lcccc}
\hline & N & MEAN & SD & $\begin{array}{c}\text { Sig. } \\
\text { Uji t }\end{array}$ \\
\cline { 1 - 3 } $\begin{array}{l}\text { Pre- } \\
\text { test }\end{array}$ & 43 & 70,72 & 3.466 & $\mathbf{0 , 0 0}$ \\
\cline { 1 - 3 } $\begin{array}{l}\text { Post - } \\
\text { test }\end{array}$ & 43 & 90,44 & 6.306 & \\
\hline
\end{tabular}

Table 4 Normality Test Data Pre-test and Posttest of 1E grade students of 2 Stikes Bina Sehat PPNI Mojokerto 2017-2018 school year.

\begin{tabular}{|c|c|c|c|c|c|c|}
\hline & \multicolumn{3}{|c|}{$\begin{array}{l}\text { Kolmogorov- } \\
\text { Smirnov }\end{array}$} & \multicolumn{3}{|c|}{ Shapiro - Wilk } \\
\hline & $\begin{array}{c}\text { Statis } \\
\text { tic }\end{array}$ & $\begin{array}{l}\text { d } \\
\text { f }\end{array}$ & $\begin{array}{c}\mathrm{Si} \\
\mathrm{g}\end{array}$ & $\begin{array}{l}\text { Statis } \\
\text { tic }\end{array}$ & $\begin{array}{l}\text { d } \\
\text { f }\end{array}$ & $\begin{array}{c}\mathrm{Si} \\
\mathrm{g}\end{array}$ \\
\hline Pr & .156 & 4 & - & .932 & 4 & • \\
\hline $\mathbf{e}$ & & 3 & 01 & & 3 & 01 \\
\hline $\begin{array}{l}\text { tes } \\
t\end{array}$ & & & $\mathbf{0}$ & & & 4 \\
\hline Po & .114 & 4 & - & .933 & 4 & . \\
\hline st & & 3 & 19 & & 3 & 01 \\
\hline $\begin{array}{l}\text { tes } \\
\text { t }\end{array}$ & & & $\mathbf{0}$ & & & 5 \\
\hline
\end{tabular}

\section{DISCUSSION}

\section{General Data}

Based on table 1, it can be concluded that the minimum pre-test results from respondents 43 semester 1E class 2 students Nursing 2017-2018 academic year Stikes Bina Sehat Mojokerto PPNI is 65 and maximum is 78, while the post-test minimum score is 43 students by 80 and maximum by 100 .

\section{Specific Data}

Based on table 1, it can be concluded that descriptive statistics analysis of respondents 43 semester 1E semester 2 students Nursing year 2017-2018 academic year Stikes Bina Sehat Mojokerto PPNI pre-test average score (70.72) and average score Post test $(90,44)$ and the standard deviation of the pre-test $(3,466)$ and the standard deviation post-test $(6,307)$.

Whereas in table 2 data the normality test is a test conducted with the aim of assessing the distribution of data in a group of data or variables, whether the distribution of data was normal or not which means that the data was normally distributed or taken from a normal population. This test is done in two ways:

1. The Kolmogorof Smirnov test is to compare the distribution of data (which will be tested for normality) with the standard normal distribution. From the results of data processing with $\mathrm{p}$ Value 5\% (0.05) or $10 \%$ (0.1) it was found that the significance of both the pre-test and post-test values were above 0.1 or 0.05 . The pre-test value is 0.10 while the post-test value is 1.90 which means the data to be tested does not have a significant difference, then the data is normal. 
2. The ShapiroWilk test also shows that the data is normal. The significance value of the pre-test is 0.14 and the post-test is 0.15 above $p$ Value. From here it shows that there is no significant difference in the distribution of normal normal data. So the data is normal.

For $t$ test (Paired $t$ test) can be seen in table 1 , it can be concluded that the test (Data difference test) is 0.00 (smaller than alpha ( $p$ Value) 0.1 means that $\mathrm{Ho}$ is rejected and $\mathrm{Hi}$ is accepted which means there is an influence significant cooperative learning method assisted individualy type team towards learning outcomes of Islamic religious courses in class $1 \mathrm{E}$ semester 2 of the 2017-2018 academic year at Stikes Bina Sehat PPNI Mojokerto.

\section{CONCLUSION}

Based on the results of research and discussion stated that the cooperative learning model assisted individually team type had a significant effect on the learning outcomes of Islamic religious courses, this can be seen from the results of the calculation of the $t$ test (data difference test) obtained significant 0.00 (smaller than alpha (p Value) 0,1 means that Ho is rejected and $\mathrm{Hi}$ is accepted, which means there is a significant effect of cooperative learning method assisted individually team type on the learning outcomes of Islamic religion courses in class 1E in semester 2 of the 20172018 school year at Stikes Bina Sehat PPNI Mojokerto.

\section{SUGESTION}

\section{General}

Hopefully this research can bring benefits to anyone who wants to take lessons in it.

\section{Specific}

226
For anyone who wants to use the Team Assisted Individually method in a study, make it like this simple research example.

\section{REFERENCES}

Cohen, Louis, Lawrence Manion, and Keith Morrison. 2011. Educational Research Research Method in Education.

Development, Organization for Economic Cooperation and, and Asian Development Bank. 2015. Far Eastern Survey Education in Indonesia: Rising to the Challenge.

Duflo, Esther. 2001. "Schooling and Labor Market Consequences of School Construction in Indonesia:

Evidence from an Unusual Policy

Experiment." American Economic

Review.

Finkelstein, Lawrence S. 1951. "Education in Indonesia." Far Eastern Survey.

Johnson, David W., Roger T. Johnson, and Mary Stanne. 2000.

"Cooperative Learning Methods :

A Meta-Analysis." Methods.

Latuconsina, Nurfitri Dara. 2018.

"Penelitian Eksperimen." In

Metode Penelitian Kesehatan,. 
Pashler, Harold, Mark McDaniel, Doug

Rohrer, and Robert Bjork. 2009.

"Learning Styles Concepts and

Evidence." Psychological Science

in the Public Interest, Supplement.

Sugiono. 2016. "Metode Penelitian

Kombinasi." In Metode Penelitian

Kombinasi,.

Wati, Yuli Ratna, Suryadi Budi Utomo, and Tri Redjeki. 2014. "Efektivitas Metode Pembelajaran Kooperatif

Tipe Teams Assisted

Indidualization (TAI) Dengan

Media Komik Terhadap Prestasi

Belajar Siswa Pada Materi

Hidrokarbon Kelas X SMA Negeri

1 Kartasura Tahun Pelajaran

2012/2013.” Jurnal Pendidikan

Kimia.

Wenger, Etienne. 1999. Learning in doing Communities of Practice:

Learning, Meaning, and Identity. 